Edukatif : Jurnal Ilmu Pendidikan Volume 2 Nomor 1 April 2020 Halm 85-92

EDUKATIF: JURNAL ILMU PENDIDIKAN

Research \& Learning in Education

https://edukatif.org/index.php/edukatif/index

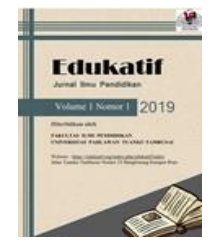

\title{
STRATEGI GURU DALAM MENUMBUHKAN KEMANDIRIAN BELAJAR PESERTA DIDIK SEKOLAH DASAR
}

\author{
Rifky $^{1}$ \\ Universitas Kristen Satya Wacana, Jawa Tengah, Indonesia \\ e-mail : komarrifky86@gmail.com ${ }^{1}$
}

\begin{abstract}
Abstrak
Strategi adalah pendekatan secara keseluruhan yang berkaitan dengan pelaksanaan gagasan,perencanaan,dan eksekusi sebuah aktifitas dalam kurun waktu. Strategi sangat diperlukan guru dalam menumbuhkan kemandirian belajar peserta didik. Strategi pembelajaran merupakan serangkaian kegiatan pembelajaran yang harus dikerjakan guru dan peserta didik agar tujuan pembelajaran dapat dicapai secara efektif dan efisien. Dengan demikian strategi menurupakan alat atau cara yang sangat ekektif dalam menumbuhkan mandiri belajar pada diri seorang peserta didik. Strategi belajar sangat penting bagi guru karena strategi akan mempermudah proses pembelajaran sehingga tujuan pembelajaran dapat dicapai. Peserta didik belajar tidak hanya menerima pengetahuan itu begitu saja tetapi peserta didik juga harus mengolah pengetahuan tersebut dengan menggunakan akal pikiran yang mereka miliki. Dengan menggunakan strategi mandiri belajar peserta didik dapat menumbuhkan rasa ingin belajar dengan sendirinya. Strategi mandiri belajar sendiri merupakan strategi yang bertujuan untuk membangun inisiatif individu, kemandirian, dan peningkatan kemampuan diri peserta didik. Strategi mandiri belajar ini bertujuan agar peserta didik mampu belajar mandiri dengan adanya dorongan dari dalam diri peserta didik untuk belajar dengan kemauan sendiri, pilihanya sendiri dan rasa tanggung jawab yang ada dalam diri peserta didik. Untuk mencapai tujuan dalam menumbuhkan kemandirian belajar peserta didik kita perlu memahami aspek-aspek yang harus diperhatikan.
\end{abstract}

Kata kunci : strategi guru, mandiri belajar

\begin{abstract}
Strategy is an overall approach related to the implementation of ideas, planning, and execution of an activity in a period of time. Strategy is really needed by the teacher in growing student learning independence. Learning strategies are a series of learning activities that must be done by teachers and students so that learning objectives can be achieved effectively and efficiently. Thus the strategy is a tool or a very effective way to foster independent learning in a student. Learning strategies are very important for teachers because the strategies will facilitate the learning process so that learning objectives can be achieved. Learners not only accept knowledge just like that but students must also process this knowledge by using the minds they have. By using an independent learning strategy students can foster a sense of learning by themselves. The self-study strategy itself is a strategy that aims to build individual initiative, independence, and improvement of students' self-abilities. This independent learning strategy aims to make students able to learn independently with the encouragement from within the students to learn on their own accord, their own choice and a sense of responsibility that exists within students. To achieve the goal of growing students' learning independence we need to understand the aspects that must be considered.
\end{abstract}

Keywords: teacher strategy, independent learning

@Edukatif: Jurnal Ilmu Pendidikan 2020

$\triangle$ Corresponding author :

Address : Jawa Tengah

Email : komarrifky86@gmail.com

ISSN 2656-8063 (Media Cetak)

Phone :

ISSN 2656-8071 (Media Online) 


\section{PENDAHULUAN}

Pendidikan menurut UU No.20 Tahun 2003 tentang Sistem Pendidikan Nasional adalah usaha dengan sengaja dan terencana untuk menciptakan suasana belajar dan proses pembelajaran agar peserta didik secara aktif menggembangkan potensi dirinya untuk mempunyai kekuatan spiritual agama, pengendalian, kepribadian, kecerdasan, akhlak mulia, serta keterampilan yang di perlukan dirinya, masyarakat, bangsa, dan negara. Didalam pendidikan tidak mungkin terlepas dengan strategi dalam pembelajaran. Strategi mandiri belajar sendiri merupakan strategi yang bertujuan untuk membangun inisiatif individu, kemandirian, dan peningkatan kemampuan diri peserta didik. Strategi mandiri belajar ini bertujuan agar peserta didik mampu belajar mandiri dengan adanya dorongan dari dalam diri peserta didik untuk belajar dengan kemauan sendiri, pilihanya sendiri dan rasa tanggung jawab ang ada dalam diri peserta didik. Untuk mencapai tujuan dalam menumbuhkan kemandirian belajar peserta didik kita perlu memahami aspek-aspek yang harus diperhatikan. Kemandirian belajar terdiri dari 4 aspek yaitu berdiri sendiri, menyelesaikan masalah, tanggung jawab dan inisiatif dan kreativitas. Untuk dapat memaksimalkan kemandirian belajar keempat aspek itu perlu adanya strategi yang tepat dalam sikap mandiri belajar yang dapat dikembangkan oleh guru. Peserta didik tersebut belum memiliki kemandirian dalam belajar. Maka dari itu, bagaimana usaha guru untuk menumbuhkan kemandirian belajar peserta didik dengan cara memberi motivasi dan membuat perencanaan mata pelajaran sehingga peserta didik lebih termotivasi. Berdasarkan penjelasan di atas penulis tertarik untuk menulis tentang "Upaya Guru Dalam Menumbuhkan Kemandirian Belajar Siswa Di SD”. Pada rumusan masalah di atas maka tujuan dari penulis adalah untuk mendeskripsikan berbagai macam strategi guru dalam upaya untuk menumbuhkan kemandirian belajar peserta didik di sekolah dasar dan untuk mengetahui strategi yang tepat untuk menumbuhkan kemandirian belajar peserta didik. Manfaat yang diharapkan oleh penulis dari penelitian ini adalah bagi peneliti dapat menambah wawasan, pengetahuan dan pengalaman dalam meneliti strategi dalam upaya menumbuhkan kemandirian belajar siswa, bagi guru sebagai referensi untuk lebih memperhatikan strategi dalam menumbuhkan kemandirian belajar yang dimiliki siswa khususnya siswa sekolah dasar.

\section{METODE PENELITIAN}

Metode yang digunakan dalam artikel yang berjudul "Strategi Guru Dalam Menumbuhkan Kemandirian Belajar Siswa Sekolah Dasar" menggunakan pendekataan kepustakaan. Pendekatan kepustakaan merupakan langkah yang penting dimana setelah seorang peneliti menentukan topik penelitian, langkah selanjutnya adalah melakukan kajian yang berkaitan dengan teori yang berkaitan dengan topik penelitian. Dalam pencarian teori, peneliti akan menggumpulkan informasi sebanyakbanyaknya dari kepustakaan yang berhubungan. Sumber-sumber kepustakaan dapat diperoleh dari buku, jurnal, majalah, hasil-hasil penelitian (tesis dan disertasi), dan sumber-sumber lain yang sesuai (Nazir,1998:112). Dalam penelitian pustaka hal yang harus dilakukan peneliti adalah pertama: peneliti tidak harus melakukan penelitian langsung 
namun hanya perlu berhadapan langsung dengan data dan angka tanpa perlu melakukan penelitian langsung, kedua data pustaka harus "siap pakai" artinya peneliti tidak harus melakukan penelitian lapangan melainkan dengan melihat sumber data yang akan digunakan.

Berdasarkan uraian uraian di atas artinya pengumpulan data dilakukan dengan melakukan perluasan terhadap berbagai sumber data seperti jurnal, tesis, buku-buku maupun dokumendokumen lain yang relevan (dalam bentuk cetak maupun elektronik). Penelitian ini bersifat kualitatif yang lebih mengutamakan analisis, penemuan, dan penyampaian data yang sudah dikumpulkan. Analisis yang digunakan bersifat deskriptif.

\section{HASIL DAN PEMBAHASAN PENELITIAN}

\section{Apa itu Strategi ?}

Menurut David (2011:18-19) Strategi adalah sarana bersama dengan tujuan jangka panjang yang hendak dicapai, sedangkan menurut Rangkuti (2013:183) berpendapat bahwa strategi adalah perencanaan induk yang komprehensif, yang menjelaskan bagaimana lembaga akan mencapai semua tujuan yang telah ditetapkan berdasarkan misi yang telah di tetapkan sebelumnya. Dari kedua pendapat di atas dapat disimpulkan bahwa strategi adalah serangkaian cara yang dilakukan untuk mencapai tujuan yang diinginkan. Setiap orang mempunyai strategi, semua orang memiliki tujuan yang hendak dicapai seperti halnya guru. Salah satu hal yang hendak dicapai guru adalah menumbuhkan menumbuhkan sikap mandiri belajar pada peserta didik. Mandiri adalah sikap tidak bergantung pada orang lain, kemandirian belajar diperlukan oleh peserta didik agar secara suka rela mau belajar tanpa adanya paksaan.

George J. Mouly dalam Trianto (2010:9) menyatakan bahwa belajar adalah proses perubahan tingkah laku seseorang berkat adanya pengalaman. Belajar merupakan suatu keharusan bagi peserta didik karena dengan belajar peserta didik dapat menemukan hal-hal baru, pengetahuan serta pengalaman baru sehingga akan memperkaya dirinya sebagai bekal terjun dalam masyarakat. Mengapa demikian? Belajar melatih otak seseorang untuk berpikir sehingga seorang individu akan terlatih dalam berpikir dan menyikapi sesuatu sehingga mampu menjadi bangsa yang berwawasan dan disegani oleh bangsa lain. Belajar dapat dilakukan secara bersama-sama dengan didampingi oleh seorang pendamping dalam konteks pendidikan di sekolah ialah guru maupun orangtua dalam konteks lingkungan keluarga, maupun dilakukan secara mandiri, menurut KBBI mandiri adalah dalam keadaan berdiri sendiri, tidak bergantung pada orang lain.

\section{Aspek- aspek Mandiri Belajar}

Dalam menumbuhkan kemandirian belajar peserta didik tentunya harus memperhatikan aspek-aspek yang mempengaruhi kemandirian belajar. Aspekaspek kemandirian belajar menurut Yurniadi dan Halida (2012) aspek kemandirian belajar terdiri dari :

a. Berdiri sendiri

Kemampuan untuk menentukan sendiri apa yang ingin dilakukan tanpa adanya 
paksaan dari orang lain. Guru dapat menumbuhkan sikap berdiri sendiri dengan cara memberinya motivasi dan pengertian tentang pentingnya kepercayaan diri dalam belajar tanpa adanya pengaruh dari orang lain.

b. Menyelesaikan masalah

Guru dapat membentuk sikap menyelesaikan masalah peserta didik dalam pembelajaran misalnya peserta didik dilatih untuk mampu menyelesaikan masalah dengan berdiskusi dengan temanya, berdiskusi dengan orang tuanya, atau dengan cara yang lain yang berkaitan dengan penyelesaian masalah peserta didik tanpa harus bergantung kepada orang lain.

c. Tanggung jawab

Guru dapat membentuk sikap tanggung jawab peserta didik dengan memberinya tugas yang harus dikerjakan dan diberi batasan waktu penyelesaiannya, untuk membentuk sikap tanggung jawab itu guru memberikan hadiah bagi peserta didik yang mampu menyelesaikan tugasnya dengan tepat waktu dan memberi hukuman bagi peserta didik yang tidak mampu menyelesaikan tugasnya dengan tepat waktu. Hukuman tidak harus dalam bentuk hukuman fisik melainkan dengan pengurangan nilai atau memberikan masukan dan teguran.

d. Inisiatif dan kreativitas

Sikap inisiatif dan kreativitas dapat dibentuk dengan guru memberi kesempatan kepada peserta didik untuk mengembangkan kreativitasnya dan bekerja sesuai dengan pemikiranya tidak menghalangi peserta didik untuk berkreasi sehingga peserta didik dapat mengembangkan ide dan pemikiranya. Selain itu guru memberi kesempatan kepada peserta didik untuk mengemukakan ide dan gagasanya kepada teman-temanya.

Penjelasan diatas merupakan aspek-aspek dalam kemandirian belajar sehingga dapat disimpulkan bahwa kemandirian belajar pada peserta didik dapat ditumbuhkan dan dikembangkan melalui berbagai aspek seperti berdiri sendiri, menyelesaikan masalah, tanggung jawab dan inisiatif dan kreatif.

\section{Faktor penghambat kemandirian belajar}

Mandiri belajar dapat diartikan sebagai proses perubahan tingkah laku berkat adanya pengalaman yang dilakukan karena dorongan dari dalam diri sendiri, tidak dituntut oleh orang lain, dilakukan atas dasar dorongan pribadi bukan atas kehendak orang lain. Dewasa ini banyak sekali peserta didik yang tidak punya semangat dalam belajar sehingga suasana belajar mandiri tidak dapat terbentuk. Lunturnya semangat belajar pada anak dipengaruhi oleh beberapa faktor yang diuraikan sebagai berikut :

a. Faktor Internal (Faktor yang berasal dari dalam diri individu)

- Sebab kemalasan karena faktor fisik

Kondisi fisik seorang peserta didik juga sangat mempengaruhinya dalam belajar, kondisi tubuh yang kurang sehat otomatis akan mengganggu saraf sensorik dan saraf motorik peserta didik sehingga informasi 
yang ia dapat atau ia pelajari tidak dapat di teruskan ke otak dengan maksimal. Keadaan fisik peserta didik yang kurang sehat juga mengakibatkan kondisi mudah mengantuk, mudah lelah, pusing dan kesulitan konsentrasi dalam memproses bahan pelajaran melalui inderanya.

- Sebab kemalasan karena faktor psikologis

Faktor psikologis meliputi bakat, minat, motivasi serta kesehatan mental peserta didik, dimana dalam belajar peserta didik harus siap secara psikologis agar mereka dapat memproses dengan maksimal setiap materi pembelajaran yang diberikan.

b. Faktor Eksternal (Faktor yang berasal dari luar diri individu peserta didik )

- Faktor Keluarga

Keluarga merupakan lingkungan pertama yang dikenal oleh peserta didik sejak ia dilahirkan, faktor didikan keluarga, cara asuh, serta hubungan antara orang tua dan anak memberi pengaruh besar terhadap peserta didik. Pola asuh yang salah serta hubungan antara orangtua dan anak yang kurang erat dapat menimbulkan masalah motivasi belajar.

- Faktor Lingkungan

Lingkungan yang nyaman sangat bagus bagi konsentrasi peserta didik sehingga peserta didik akan lebih fokus terhadap materi pembelajaran, begitupun sebaliknya lingkungan yang gaduh dan ramai akan memecah konsentrasi peserta didik sehingga menghambat aktivitas belajarnya.

- Faktor Kesalahan Penggunaan Metode
Penggunaan metode pembelajaran seharusnya disesuaikan dengan karakteristik peserta didik sehingga sebelum kegiatan belajar mengajar dilakukan maka guru harus menggunakan metode pembelajaran yang sesuai dengan peserta didik agar penyampaian materi dapat lebih mudah dilakukan.

Dalam hal ini berarti ada beberapa faktor baik yang berasal dari dalam diri individu peserta didik (internal) maupun faktor yang berasal dari luar individu peserta didik (eksternal).

\section{Upaya Guru dalam Menumbuhkan Sikap Mandiri Belajar}

Beberapa upaya dapat dilakukan untuk menumbuhkan sikap mandiri belajar bagi peserta didik, peran guru sangat berpengaruh dalam menumbuhkan motivasi peserta didik karena guru merupakan sosok yang dianggap teladan dan dianggap contoh bagi peserta didik. Berikut beberapa peran guru :

a. Guru sebagai pendidik

Bagi siswa SD guru merupakan sosok yang paling berpengaruh terhadap perilaku peserta didik, bagi siswa guru merupakan sosok panutan yang ditiru oleh peserta didik sehingga guru sebagai pendidik wajib memenuhi standar kualitas guru yang ideal, membentuk pribadi yang berwibawa, disiplin, bertanggung jawab, tegas, dan mandiri.

b. Guru sebagai pengajar

Dalam hal ini guru berperan untuk membantu peserta didik untuk membentuk komepetensinya, membantu peserta didik 
untuk memahami sesuatu yang sebelumnya tidak diketahui, menjadikan peserta didik yang sebelumnya tidak bisa menjadi bisa, yang belum mengerti menjadi mengerti.

c. Guru sebagai pembimbing

Dalam hal ini guru bertugas untuk mengarahkan peserta didik serta memberikan petunjuk dan arahan bagi peserta didik agar tercapai tujuan yang hendak dituju.

d. Guru sebagai penasihat

Selain membimbing dan mengajar tugas guru yang lain diantaranya adalah memberikan edukasi dan pendidikan moral bagi peserta didik sehingga selain memberikan ilmu pengetahuan guru juga bertanggung jawab dalam menanamkan nilai-nilai moral pada peserta didik, oleh karena itu guru harus senantiasa melakukan observasi terhadap perilaku peserta didik agar tidak terjadi penyimpangan, dan andai kata terjadi penyimpangan tugas guru adalah memberikan nasihat agar peserta didik tidak mengulangi perbuatannya.

Diatas merupakan beberapa peran guru diantara lain sebagai pendidik, pengajar, pembimbing dan penasihat. Dapat disimpulkan bahwa guru sangat mempengaruhi perilaku peserta didik. Guru juga harus mampu menumbuhkan perilaku semangat belajar pada diri peserta didik sehingga peserta didik secara mandiri mau belajar tanpa harus merasa dipaksa.

Beberapa strategi yang bisa dilakukan :

a. Strategi Guru

- Memberikan materi yang unik dan menyenangkan
Guru dalam menyampikan materi harus disampaikan secara sederhana tidak berbelitbelit serta menggunakan bahasa yang mudah dipahami oleh peserta didik, melibatkan peserta didik secara langsung dalam pembelajaran sehingga peserta didik tidak bosan mendengarkan penjelasan guru yang dilakukan dengan ceramah, menghubungkan materi dengan kedidupan sehari-hari yang dialami oleh peserta didik atau kontekstual sehingga peserta didik lebih mudah memahami materi.

- Menyampaikan materi dengan cara yang sederhana dan tidak membosankan

- Membangkitkan motivasi peserta didik dengan memberikan reward

Guru dalam kegiatan belajar mengajar dapat membangkitkan semangat peserta didik dengan iming-iming berupa reward dapat berupa nilai, skor maupun hadiah.

- Membentuk situasi belajar yang interaktif Menjadikan peserta didik sebagai pusat pusat pembelajaran (student center), guru mengusahakan agar seluruh peserta didik untuk berpartisipasi agar tercipta suasana belajar yang aktif, dalam hal ini guru berperan sebagai fasilitator dan mediator

- Menciptakan kondisi belajar yang kondusif Guru mengorganisasikan kelas agar tercipta suasana yang teratur,hal yang dapat dilakukan adalah dengan membagi kelas menjadi beberapa kelompok secara heterogen. Peserta didik dapat berbagi pengetahuan dan informasi dengan sesama temanya. Selain itu guru mengontrol kelas agar diskusi berjalan dengan lancar dengan baik dan kondusif. 
- Mengapresiasi peserta didik dan senantiasa memberikan masukan untuk perbaikan peserta didik.

Setelah kegiatn diskusi selesai siswa mempresentasikan hasil dikusi bersama temanya, guru mendegarkan penjelasan dari siswa kemudian memberikan masukan atau tambahan sebagai bahan perbaikan

\section{SIMPULAN}

Strategi adalah pendekatan secara keseluruhan yang berkaitan dengan pelaksanaan gagasan, perencanaan, dan eksekusi sebuah aktifitas dalam kurun waktu. Strategi sangat diperlukan guru dalam menumbuhkan kemandirian belajar peserta didik. Strategi pembelajaran merupakan serangkaian kegiatan pembelajaran yang harus dikerjakan guru dan peserta didik agar tujuan pembelajaran dapat dicapai secara efektif dan efisien. Dengan berbagai konsep kemandirian belajar guru dapat meningkatkan kemandirian belajar peserta didik supaya dapat tercapinya sikap kemandirian dalam diri peserta didik. Ada juga berbagai hambatan yang dialami guru dalam menumbuhkan sikap kemandirian belajar dalam diri peserta didik baik faktor internal maupun faktor ekternal. Guru juga mempunyai berbagai strategi untuk menumbuhkan sikap kemandirian belajar peserta didik antara lain menciptakan suasana belajar yang aktif, menyampaikan materi dengan cara yang sederhana dan tidak membosankan, membangkitkan motivasi peserta didik dengan memberikan reward, membentuk situasi belajar yang interaktif,menciptakan kondisi belajar yang kondusif, mengapresiasi peserta didik dan senantiasa memberikan masukan untuk perbaikan peserta didik.

\section{DAFTAR PUSTAKA}

Dalam Tritanto. (2010). Mendesain Model Pembelajaran Inovatif Pregresif Konsep, Landasan dan Implementasinya Pad Kurikulum Tingkat Satuan Pendidikan (KTSP). Jakarta: Kencana Prenada Group.

David, R Fred. Strategic Management Manajemen Strategi konsep Edisi 12. In R. F. David. Bandung.

Depdiknas. (2003). Undang-Undang RI No.20 Tahun 2003 Tentang Sistem Pendidikan Nasional. Jakarta.

Freddy Rangkuti. (2013). Teknik Membedah Kasus Bisnis Analisis SWOT Cara Perhitungan Bobot. Ranting, dan OCAI. Jakarta: PT Gramedia Pustaka Utama.

Halida dan Yurniadi . (2012). Aspek-Aspek Kemandirian Belajar.

Nazir. (1998). Metode Penelitian. Jakarta: Rineka Cipta. 
92 Strategi Guru Dalam Menumbuhkan Kemandirian Belajar Peserta Didik Sekolah Dasar-Rifky

Edukatif : Jurnal Ilmu Pendidikan Vol 2 No 1 April 2020 p-ISSN 2656-8063 e-ISSN 2656-8071 